\title{
DYPLOMACJA NAUKOWA JAKO FORMA WSPÓŁPRACY I RYWALIZACJI W ARKTYCE
}

\author{
Michał Łuszczuk \\ Wydział Politologii \\ Uniwersytet Marii Curie Skłodowskiej w Lublinie \\ e-mail: michal.luszczuk@poczta.umcs.lublin.pl
}

\begin{abstract}
Streszczenie: W kontekście wyzwań wynikających z nasilających się następstw zmian klimatu oraz wzrostu międzynarodowego znaczenia regionu Arktyki pojawia się istotne zagadnienie specyfiki relacji zachodzących współcześnie między naukowcami a dyplomatami oraz politykami w zakresie kształtowania oraz realizowania polityki zagranicznej państwa. W artykule w oparciu o koncepcję dyplomacji naukowej oraz analizę wybranych przykładów interakcji pomiędzy światem nauki oraz polityki zagranicznej w Arktyce wskazuje się na dwuwymiarowy charakter dyplomacji naukowej. Z jednej strony jest to wymiar narodowy - ukierunkowany na realizacje partykularnych interesów państw, z drugiej zaś wymiar międzynarodowy - służący rozwojowi współpracy regionalnej i rozwiązywaniu wspólnych problemów. Ta specyficzna natura dyplomacji naukowej oznacza, iż stanowić może ona we współczesnych stosunkach międzynarodowych zarówno instrument rywalizacji, jak też mechanizm współpracy.
\end{abstract}

Słowa klucze: dyplomacja naukowa, dyplomacja, międzynarodowa współpraca naukowa, Arktyka

\section{WPROWADZENIE}

Wśród wielu obszarów badawczych nauki o stosunkach międzynarodowych szczególne miejsce zajmuje problematyka dyplomacji. Specyfika tego zagadnienia - zaskakująco często lokowanego na peryferiach przestrzeni badawczej nauki o stosunkach międzynarodowych ${ }^{1}$ - jest w znacznym stopniu warunkowana przez wieloznaczność samego pojęcia „dyplomacja”, różnorodność konceptualizacji dyplomacji jako kategorii badawczej w głównych nurtach badawczych, jak również

1 T. Łoś-Nowak, O potrzebie rekonstrukcji przestrzeni badawczej w nauce o stosunkach międzynarodowych. Refleksje natury polityczno-normatywnej, systemowej i metaforycznej, „Przegląd Politologiczny" 2011, tom XVI, nr 1, s. 25-38; M. Pietraś, Przestrzeń badawcza nauki o stosunkach międzynarodowych, „Politeja” 2015, vol. 36, tom 5, s. 65-97. 
ewolucję, której praktyka dyplomacji nieustannie podlega. ${ }^{2} \mathrm{~W}$ ocenie autorów głównych monografii poświęconych problematyce dyplomacji, jednym ze znamiennych przykładów transformacji dokonującej się w obrębie współczesnej dyplomacji jest powstawanie jej nowych odmian lub specjalizacji. ${ }^{3}$ Ta wielowariantowość dyplomacji, z jednej strony, wyraża jej imponującą zdolność do adaptacji w obliczu dynamicznie zmieniających się parametrów późnowestfalskiego ładu międzynarodowego ${ }^{4}$. $Z$ drugiej zaś strony, odzwierciedla różnorodność wyzwań, przed jakimi stoją współcześnie dyplomaci oraz decydenci polityczni; wyzwań bardzo często wykraczających poza katalog tradycyjnych obszarów stosunków międzynarodowych. ${ }^{5}$

Jedną z odmian dyplomacji stanowi dyplomacja naukowa, którą - wstępnie - można określić jako sferę współdziałania przedstawicieli świata nauki oraz świata polityki w zakresie dyplomacji, polityki zagranicznej oraz polityki międzynarodowej. ${ }^{6}$ Warto w tym miejscu od razu podkreślić, iż jakkolwiek związki występujące między wiedzą a władzą nie są typowym obszarem badań z zakresu stosunków międzynarodowych ${ }^{7}$, to $\mathrm{w}$ rzeczywistości relacje te bardzo często miały duży, a współcześnie mają jeszcze większy, wpływ na dzieje świata w wymiarze politycznym i gospodarczym. ${ }^{8}$ Uzasadnionym będzie zatem stwierdzenie, iż bezpośrednia kooperacja naukowców oraz dyplomatów i polityków nie jest czymś całkowicie nowym w kontekście historii stosunków międzynarodowych. ${ }^{9}$ Nowym jest jednak jej obecny charakter: skala, waga, dynamika, a poniekąd i in-

2 B. Surmacz, Ewolucja wspótczesnej dyplomacji, Lublin 2015.

3 R.P. Barston, Modern diplomacy, 4th edition, London 2013; Routledge Handbook of Public Diplomacy, N. Snow, Ph.M. Taylor (eds), London 2009; Nowe oblicza dyplomacji, B. Surmacz (red.), Lublin 2013.

4 K. Marzęda, M. Pietraś (red.), Późnowestfalski ład międzynarodowy, Lublin 2008.

5 B. Surmacz, op. cit.

6 D. Copeland, Science Diplomacy, [w:] The SAGE Handbook of Diplomacy, C. M. Constantinou, P. Kerr, P. Sharp (eds), London 2016.

7 Na przykład w polskiej literaturze z zakresu stosunków międzynarodowych sporadycznie podejmowany był temat międzynarodowej współpracy naukowo-technicznej, zob.: E. Haliżak, Wspótpraca naukowo-techniczna Wschód-Zachód, Warszawa 1988a; Idem, Międzynarodowe stosunki naukowo-techniczne i zagraniczna polityka naukowo-techniczna, [w:] Zmienność i instytucjonalizacja stosunków międzynarodowych, J. Kukułka (red.), Warszawa 1988b; Idem, Internacjonalizacja nauki i techniki, [w:] Internacjonalizacja życia narodów i państw, J. Kukułka (red.), Warszawa 1991. Do nielicznych bardziej aktualnych opracowań na temat znaczenia wiedzy dla rozwoju stosunków międzynarodowych należy z kolei tekst A. Bogdół-Brzezińskiej, Międzynarodowe struktury wiedzy i innowacji - mechanizmy zmiany, aktualne trendy i uczestnicy, [w:] Geoekonomia, A. Aleksy-Szucsich, E. Haliżak (red.), Warszawa 2012. Wyjątkowym opracowaniem jest w tym kontekście pozycja: A. Wojciuk, Imperia wiedzy. Edukacja i nauka jako czynniki sity państwa na arenie międzynarodowe, Warszawa 2016.

8 Zob. szerzej: A. Wojciuk, op. cit.

9 Zob. E. Skolnikoff, The elusive transformation. Science, technology, and the evolution of international politics, Princeton 1992; T. Flink, U. Schreiterer, Science diplomacy at the intersection of S\&T policies and foreign affairs: toward a typology of national approaches, „Science and Public Policy” 2010, vol. 27, nr 9, s. 665-677. 
stytucjonalizacja. Te właśnie atrybuty sprawiają, iż zjawisko to dopiero niedawno doczekało się swej ogólnej nazwy, na bazie której następnie zaczęto konstruować oryginalną koncepcję badawczą. Jak bowiem zauważa van Langenhove, „dyplomacja naukowa" to pojęcie obecnie wykorzystywane zarówno do identyfikowania specyficznych działań w obrębie praktyki dyplomatycznej, jak również kategoria służącą do opisywania i wyjaśniania określonych działań politycznych podejmowanych na płaszczyźnie naukowej. ${ }^{10}$

Na podstawie analizy debaty naukowej dotyczącej współczesnego znaczenia oraz kształtu relacji między badaczami a dyplomatami należy stwierdzić, iż pomimo rosnącej popularności samego terminu „dyplomacja naukowa”, to oparta na nim koncepcja nie jest jeszcze w pełni dojrzała czy kompletna ${ }^{11}$. Częściowo można tę sytuację zapewne wytłumaczyć mankamentami związanymi z różnymi interpretacjami samego pojęcia „dyplomacja”. Wyjaśnienie to jednak nie wydaje się wystarczające w obliczu deficytów dotyczących potencjału eksplanacyjnego tej koncepcji, szczególnie w zakresie powodów podejmowania oraz rezultatów prowadzenia dyplomacji naukowej zarówno z perspektywy polityki zagranicznej państw, jak też ich wielostronnej kooperacji.

W niniejszym artykule - poprzez zbadanie wybranych przykładów zjawisk oraz procesów zachodzących współcześnie pomiędzy światem polityki a nauki, które dotyczą regionu Arktyki - podjęta zostanie zatem próba wzmocnienia przydatności badawczej koncepcji dyplomacji naukowej. Zostanie to zrealizowane przede wszystkim poprzez ustalenie jaka jest specyfika dyplomacji naukowej w kontekście dwóch podstawowych stanów stosunków międzynarodowych: współpracy i rywalizacji. Pośrednio pozwoli to na określenie dlaczego państwa decydują się na prowadzenie dyplomacji naukowej oraz jakie są jej rezultaty zarówno w wymiarze krajowym (narodowym), jak też międzynarodowym.

Wybór współczesnych stosunków międzynarodowych w Arktyce, a dokładniej ich naukowo-dyplomatycznego fragmentu, jako pola do przetestowania i rozwinięcia użyteczności kategorii dyplomacji naukowej nie jest przypadkowy. Otóż, Arktyka na początku XXI wieku to nie tylko swoiste laboratorium stosunków międzynarodowych, lecz - co podkreśla R.M. Czarny - to także obszar, którego dokładniejsze poznanie naukowe leży zarówno w interesie wszystkich państw regionu, jak również wielu innych położonych poza jego granicami ${ }^{12}$. Relacje pomiędzy nauką a dyplomacją oraz między nauką a polityką międzynarodową są teraz w Arktyce szczególnie rozbudowane oraz istotne, co więcej - ich waga w kontekście nasilających się następstw zmian klimatu - jedynie może wzrastać. Ta obserwacja pozwala przyjąć założenie, że koncepcja dyplomacji naukowej

10 L. van Lengenhove, Science Diplomacy: New Global Challenges, New Trend, RSIS Commentary No-082-12, April 2016, dostępny on-line: https:/www.rsis.edu.sg/wp-content/uploads/2016/04/CO16082.pdf (23.02.2017).

${ }_{11}$ Podobne stanowisko przedstawia m.in. D. Copeland, op. cit.

12 R.M. Czarny, The High North. Between Geography and Politics, Heidelberg 2015, s. 24 I nast. 
jest już obecnie przydatna do opisu i wyjaśnienia sytuacji międzynarodowej na Dalekiej Północy oraz polityk arktycznych prowadzone przez wielu aktorów w tym regionie ${ }^{13}$.

Artykuł ten składa się z pięciu części. Po niniejszym wprowadzeniu, przestawiona jest dokładniej kategoria dyplomacji naukowej oraz oparta na niej koncepcja, następnie zarysowana jest historia regionu Arktyki, jako miejsca szczególnie bliskich interakcji między nauką a dyplomacją, polityką zagraniczną oraz polityką międzynarodową. W części czwartej opracowania, odwołując się do trzech głównych wymiarów dyplomacji naukowej, poddane zostały krótkiej analizie przykłady najnowszych relacji między światem nauki i polityki. W ostatniej zawierają się wnioski dotyczące problematyki zjawiska dyplomacji naukowej w Arktyce, jak również konkluzje dotyczące samej koncepcji i propozycje wzmocnienia jej walorów badawczych.

\section{DYPLOMACJA NAUKOWA JAKO ZJAWISKO ORAZ KATEGORIA BADAWCZA}

Problematyka znaczenia rozwoju wiedzy dla stosunków międzynarodowych to zagadnienie wielowymiarowe, $\mathrm{w}$ ramach którego pojawiają się niekiedy nawet sprzeczne poglądy. Jeden z takich przypadków dotyczy charakteru relacji pomiędzy światem nauki a światem polityki. Po jednej stronie znajduje się stanowisko, wedle którego światy te są nie tylko odrębnymi sferami, lecz wręcz pozostają w opozycji do siebie pod względem logiki funkcjonowania oraz obowiązujących w nich wartości aksjologicznych. ${ }^{14} \mathrm{~W}$ świecie nauki naczelne miejsce zajmuje wiedza oparta na etycznie uzyskanych i obiektywnych dowodach (evidence-based knowledge), zaś sama nauka jest postrzegana jako całkowicie wolna od wpływów polityki i ideologii. Zgodnie z tą perspektywą nauka stanowi uniwersalny język całej ludzkości, zaś badacze mają dążyć jedynie do poznania odpowiedzi na pytania dotyczące natury rzeczy. ${ }^{15} \mathrm{Z}$ kolei świat polityki jest uznawany za obszar ścierania się wpływów i interesów, w którym racje i zasady podlegają relatywizacji, są niepewne i zmienne. Polityka to zarówno dialog, jak i konflikt, a dyplomacja co najwyżej jest jej jaśniejszą stroną.

Stanowisko, pozostające w całkowitej opozycji do powyżej przedstawionego, wskazuje dla odmiany na bliskość świata nauki i polityki, na ich komplementarność w zakresie wpływu na rozwój ludzkości, zarówno w kontekście przełomowych momentów, jak i codziennej praktyki. Zgodnie z tym ujęciem, współpraca między naukowcami a decydentami politycznymi nie tylko czyni politykę bardziej

${ }_{13}$ M. Łuszczuk, Ewolucja ról międzynarodowych w regionie Arktyki, Lublin 2015.

${ }_{14}$ D. Copeland, op. cit.

15 V. Turekian et al, The Emergence of Science Diplomacy, [w:] Science Diplomacy. New Day or False Dawn?, L. Davis, R. Patman (eds), London 2014, s. 4; 
efektywną i odpowiedzialną, lecz także pozwala sterować rozwojem nauki w kierunku rozwiązywania najważniejszych i pilnych wyzwań dla poszczególnych narodów czy całej społeczności międzynarodowej. Co więcej, jak się niekiedy zauważa, nauka w zasadzie jest finansowana przez państwa, a więc jest ściśle związana $\mathrm{z}$ jego potrzebami oraz interesami. ${ }^{16}$

Ponieważ przedstawione poglądy są podejściami skrajnymi, należy uznać, iż rzeczywisty charakter i zakres relacji między nauką a polityką (w tym też dyplomacją) zawiera się gdzieś pomiędzy nimi. Co więcej, podlega on zmienności na przestrzeni dziejów - są epoki, gdy faktycznie oba światy funkcjonują niezależnie, są też okresy, gdy ich trajektorie są bardzo zbliżone.

Jak wskazują autorzy opracowania poświęconego powstaniu dyplomacji naukowej, od czasu zakończenia zimnej wojny, w dobie globalizacji dostrzec można wyraźne zbliżenie pomiędzy nauką a polityką zagraniczną, czego efektem jest rozwój dyplomacji naukowej. ${ }^{17} \mathrm{~W}$ ich ocenie dyplomacja naukowa to „proces za pomocą, którego państwa reprezentują siebie oraz swoje interesy na arenie międzynarodowej w odniesieniu do zagadnień związanych z wiedzą - jej zdobyciem, wykorzystywaniem i komunikowaniem - opartą na metodach naukowych"18. Z kolei dla uczestników warsztatów zorganizowanych przez amerykańską National Research Council w lutym 2011 roku dyplomacja naukowa to zarówno „sposób osiągania celów narodowych jako komponent tzw. soft power, jak również forma rozwoju nauki, rozwiązywania wspólnych problemów i rozwijania bezpośrednich kontaktów". ${ }^{19}$

Zanim podjęta zostanie dokładniejsza analiza form aktywności naukowo-dyplomatycznej składających się na zjawisko dyplomacji naukowej należy zwrócić uwagę na inne zagadnienie, które również dotyczy nauki i polityki międzynarodowej, a mianowicie kwestię międzynarodowej współpracy naukowej. Problematyka ta niekiedy bywa łączona $\mathrm{z}$ dyplomacją naukową ${ }^{20}$, jednak większość badaczy wskazuje, iż jest to błędne podejście, gdyż występują między nimi istotne różnice. ${ }^{21}$ Otóż, o ile dyplomacja naukowa stanowi z reguły element polityki zagranicznej państwa i służy jego interesom, to międzynarodowa współpraca naukowa dotyczy głównie dążenie do postępu naukowego i jest animowana oraz prowadzona przez jednostki lub ich grupy. ${ }^{22}$ Potwierdzenie tej tezy umożliwia

${ }^{16}$ C.S. Wagner, Science and foreign policy, The elusive partnership: science and foreign policy, "Science and Public Policy" 2002, vol. 29, nr 6, s. 409-417.

${ }_{17} \mathrm{~V}$. Turekian et al, op. cit., s. 5 i dalej.

18 Ibidem, s. 4.

19 Committee on Global Science Policy and Science Diplomacy, National Research Council, U.S. and International Perspectives on Global Science Policy and Science Diplomacy: Report of a Workshop, Washington, D.C. 2012, s. 25-26, dostępny on-line: https://www.nap.edu/ login.php?record_id=13300\&page=https $\% 3 \mathrm{~A} \% 2 \mathrm{~F} \% 2 \mathrm{Fwww}$.nap.edu $\% 2 \mathrm{Fdownload} \% 2 \mathrm{~F} 13300$ (20.02.2017).

${ }^{20}$ T. Flink, U. Schreiterer, op. cit.

${ }^{21}$ D. Copeland, op. cit.

${ }^{22}$ V. Turekian et al, op. cit., s. 6. 
ponowne przyjęcie perspektywy historycznej, które pozwoli dostrzec, iż międzynarodowa współpraca naukowa stanowiła z reguły odpowiedź na poszukiwania o stricte naukowym charakterze, natomiast dyplomacja naukowa jest - jak to zazwyczaj podkreśla się w literaturze przedmiotu - pochodną narastania konkretnych zagrożeń dla istnienia i rozwoju państw, zagrożeń, które z reguły mają charakter transgraniczny, a poprzez swą globalną skalę ,wymuszają” kooperację polityczną między różnymi państwami (i nie tylko nimi).

Warto w tym kontekście warto nawiązać do obserwacji, iż właśnie to te zjawiska - wyzwania z zakresu tzw. niskiej polityki, które wyłoniły się po zakończeniu zimnej wojny (dotyczące np. praw człowieka czy ochrony środowiska) przyczyniły się do wykształcenia się „,nowych płaszczyzn działań dyplomatycznych, a w tych obszarach aktorzy pozapaństwowi posiadają, co najmniej porównywalne, jeżeli nie większe od państw doświadczenie, wiedzę ekspercką i społeczną wiarygodność" ${ }^{23}$. Sytuacja ta stanowić może przesłankę dla zacieśniania współpracy dyplomatów i nie-dyplomatów, do swoistego partnerstwa, które B. Hocking określił mianem „dyplomacji katalitycznej”24. Wpływ tej nowej sytuacji wpływa nie tylko na powstawanie nowych odmian dyplomacji, lecz nawet na redefinicję pojęcia dyplomacji jako takiej. Na przykład R. Barston opisując współczesną dyplomację uważa, że obecnie „działania dyplomatyczne podejmowane są nie tylko i wyłącznie przez uprawnione organy państwa, lecz także „przez szerokie spectrum instytucji wewnątrzpaństwowych, przez przedstawicieli organizacji międzynarodowych, często we współpracy lub za pośrednictwem organizacji pozarządowych czy wręcz osób prywatnych". Jak z kolei zauważa A. Wojciuk, sieciowy model dyplomacji publicznej wydaje się optymalny dla prowadzenia polityki zagranicznej we współczesnych coraz bardziej złożonych uwarunkowaniach środowiskowych, gdyż właśnie sieci oferują różnorodność uczestników oraz sprzyjają uczeniu się i przetwarzaniu informacji. ${ }^{25}$ Takie ujęcie zjawiska dyplomacji bez wątpienia jest zbliżone do założeń na jakich opiera się dyplomacja naukowa.

Jedną z pierwszych prób ustalenia czym jest lub też na czym polega dyplomacja naukowa zawiera raport pt. New frontiers in science diplomacy ${ }^{26}$ będący podsumowanie debaty zorganizowanej w 2009 roku przez brytyjskie The Royal Society przy współpracy z American Association for the Advancement of Science (AAAS) ${ }^{27}$.

${ }^{23}$ B. Surmacz, op. cit., s. 35.

${ }^{24}$ B. Hocking, Catalytic Diplomacy, [w:] Innovation in Diplomatic Practice, J. Melissen (ed), Basingstoke 1999 .

${ }^{25}$ A. Wojciuk, Dylematy potęgi. Praktyczna teoria stosunków międzynarodowych, Warszawa 2010, s. 35 .

${ }^{26}$ The Royal Society, New frontiers in science diplomacy, London 2010, dostęny on-line: https:// royalsociety.org/topics-policy/publications/2010/new-frontiers-science-diplomacy/ (15.03.2017).

27 American Association for the Advancement of Science (AAAS) to międzynarodowa organizacja non-profit zajmująca się ogólnie pojętym rozwojem nauki założona w USA w 1848 roku. Od 2008 w jej ramach działa Centre for Science Diplomacy, a także wydawane jest czasopismo 
Według autorów tego opracowania dyplomacja naukowa stanowi współczesną odmianę znanych od stuleci form kooperacji pomiędzy światem nauki a światem polityki, szczególnie w jej międzynarodowym wydaniu. Przełomowym zaś momentem w intensyfikacji tej kooperacji był koniec II wojny światowej, a szczególnie użycie bomby atomowej, które unaoczniły jak potężny wpływ na bieg wydarzeń międzynarodowych może mieć zastosowanie w praktyce efektów badań naukowych. O ile jednak rezultaty badań naukowych służyć mogą celom militarnym, to również mogą być one wykorzystywane do rozwiązywania narastających i coraz bardziej złożonych problemów współczesnego świata, i właśnie to pokojowe oraz pro-rozwojowe podejście oparte na zaufaniu i międzykulturowym zrozumieniu w świetle raportu stanowić powinno główną cechę dyplomacji naukowej. Odwołując się do różnych przykładów, szczególnie z okresu zimnej wojny oraz późniejszych dekad, eksperci The Royal Society i AAAS podkreślają również, iż potencjał dyplomacji naukowej stanowi szansę na rozwiązanie wielu globalnych wyzwań, z jakimi zmaga się świat na początku XXI wieku. Wskazują w tym kontekście na zmiany klimatu, bezpieczeństwo żywnościowe, ograniczenie ubóstwa czy też redukcja potencjałów nuklearnych - problemy, których rozwiązanie wydaje się być poza zasięgiem tradycyjnej dyplomacji. ${ }^{28}$

Pozostawiając na boku walory aksjologiczne dyplomacji naukowej jako formy oddziaływania na stosunki międzynarodowe (wyraźnie oparte na założeniach zgodnych z paradygmatem liberalnym w nauce o stosunkach międzynarodowych), warto zwrócić uwagę na próbę konceptualizacji dyplomacji naukowej przedstawioną we wspomnianym raporcie. Należy to uczynić, gdyż ujęcie to - jak można odnieść wrażenie - stało się punktem odniesienia dla wielu opracowań publicystycznych, eksperckich czy wreszcie naukowych dotyczących tematu relacji między nauką a stosunkami międzynarodowymi. Otóż dyplomacja naukowa została uznana za sferę relacji zachodzących między naukowcami a decydentami politycznymi oraz dyplomatami, które można przyporządkować do jednego $\mathrm{z}$ trzech typów interakcji: (1) nauka $\mathrm{w}$ dyplomacji, (2) dyplomacja dla nauki oraz (3) nauka dla dyplomacji.

Istotą pierwszego $\mathrm{z}$ wymienionych typów - czy też jak to jest też określane - wymiarów dyplomacji naukowej jest wykorzystywanie osiągnięć naukowych w ramach polityki zagranicznej i/lub polityki międzynarodowej. W założeniu praktyka ta ma polegać na dostarczaniu politykom wysokiej jakości wiedzy naukowej, pochodzącej od niezależnych badaczy (zorganizowanych w formie międzynarodowych ciał eksperckich lub też krajowych instytucji naukowych), dzięki której decydenci będą mogli podejmować bardziej optymalne decyzje. Ta forma interakcji - w sumie polegająca na doradztwie eksperckim - wymaga z jednej

pt. Science Diplomacy (http://www.sciencediplomacy.org). Zob.: American Association for the Advancement of Science, Center for Science Diplomacy, dostępny on-line: https://www.aaas.org/ program/center-science-diplomacy (20.03.2017)

28 The Royal Society, op. cit. 
strony odpowiednich kompetencji od polityków w zakresie przyswajania wiedzy naukowej, z drugiej zaś odpowiedniego podejścia oraz umiejętności komunikacyjnych od badaczy. Efektywność nauki w dyplomacji (science in diplomacy) opiera się zatem na wzajemnym zrozumieniu odmienności sfery polityki i nauki, a jednocześnie transferze wiedzy ukierunkowanym przede wszystkim na rozwiązywanie społecznie ważkich problemów o charakterze międzynarodowym.

Podstawą drugiego wymiaru dyplomacji naukowej jest rozwijanie międzynarodowej współpracy naukowej poprzez podejmowanie określonych inicjatyw na płaszczyźnie politycznej stosunków międzynarodowych. Ta tzw. dyplomacja dla nauki (diplomacy for science) to skoncentrowanie wysiłków decydentów i dyplomatów na wzmocnieniu międzynarodowego wymiaru badań naukowych. Wzmocnienie to polegać może zarówno na odgórnym określaniu priorytetów badawczych (top-own approach), jak też wspieraniu współpracy pomiędzy poszczególnymi ośrodkami czy nawet badaczami (bottom-up approach), wciąż bowiem istnieje wiele barier w rozwoju swobodnej kooperacji naukowej. Efektem rozwijania dyplomacji dla nauki ma być jej swobodny rozkwit i rozwój w coraz większej niezależności od narodowych uwarunkowań i ograniczeń.

Wreszcie, treścią trzeciej i ostatniej odmiany dyplomacji naukowej jest wykorzystywanie nauki w relacjach międzypaństwowych (z reguły na rzecz ich poprawy i rozwoju). Ta forma interakcji między badaczami a politykami i dyplomatami - określona jako nauka dla dyplomacji (science for diplomacy) jest rozumiana jako przejaw tzw. soft power państwa, o której rosnącym znaczeniu we współczesnych stosunkach międzynarodowych świadczą badania J. Nye'a ${ }^{29}$. W tym kontekście nauka dla dyplomacji to zarówno kolejny z niemilitarnych zasobów państwa, jak też mechanizm wywierania wpływów na innych uczestników stosunków międzynarodowych. Typowymi narzędziami wykorzystywanymi w ramach tak rozumianej dyplomacji naukowej są: (1) umowy nt. współpracy naukowej, (2) nowe instytucje, stypendia naukowe i edukacyjne, (3) tzw. dyplomacja drugiej ścieżki (track two diplomacy), (4) wydarzenia naukowe - festiwale, kongresy, wystawy.

Jak dość samokrytycznie stwierdzają autorzy raportu, koncepcja dyplomacji naukowej jest jak na razie obciążona pewnymi brakami i niejednoznacznością, ma też bardzo wyraźny wymiar normatywny, a nawet postulatywny charakter. Do głównych postulatów zawartych w oparciu tą koncepcję należą: (1) konieczność unikania groźby upolitycznienia nauki, (2) poszerzanie zakresu podmiotów zaangażowanych $\mathrm{w}$ interakcje między nauką a polityką międzynarodową, (3) wspieranie możliwości ściślejszej kooperacji przedstawicieli obu światów, a także poniekąd łączenia ich zadań w formie „naukowych ambasadorów”.

Nawiązując do wskazanych postulatów - które wszak odnoszą się do sfery praktyki, a nie teorii - warto też odwołać się do opracowań powstających w Stanach Zjednoczonych, w których pojęcie dyplomacji naukowej jest coraz mocniej

29 J.S. Nye, Soft power: jak osiagnać sukces w polityce światowej, Warszawa 2007. 
obecne zarówno w ośrodkach naukowych, ośrodkach eksperckich (think tanki), jak też w instytucjach rządowych. Istotną rolę w tym procesie odgrywają osoby, które łącząc swoje doświadczenia naukowe z praktyką w zakresie polityki zagranicznej i dyplomacji przenikają pomiędzy światem nauki i polityki. Jednym z nich jest Vaughan Turekian, który od 2006 roku kierował Centrum Dyplomacji Naukowej funkcjonującym przy American Association for the Advancement of Science oraz był głównym redaktorem czasopisma Science \& Diplomacy, a w 2015 roku został mianowany na stanowisko Doradcy Sekretarza Stanu ds. Nauki i Techniki (Science and Technology Adviser to the U.S. Secretary of State). W swoim opracowaniu z 2012 roku V. Turekian wskazał, iż rozwijanie dyplomacji naukowej powinno leżeć w interesie państw, gdyż dzięki temu mają one szansę na: (1) manifestowanie swej siły lub wywieranie wpływu, (2) wyposażanie decydentów w wiedzę służącą celom politycznym oraz (3) wzmacnianie relacji dwustronnych i wielostronnych. ${ }^{30}$

Z kolei D. Copeland pisząc o zaletach dyplomacji naukowej podkreśla, iż pożytecznie łączy ona zdolność do wywierania wpływu na sprawy międzynarodowe z naukowymi metodami zdobywania wiedzy oraz związanymi z tym wartościami obiektywizmu, otwartości, współpracy, brakiem ideologicznych uprzedzeń, pewną elastycznością. ${ }^{31}$ Zdaniem tej badaczki, dyplomacja naukowa oferuje wyjątkowe możliwości nie tylko w rozwiązywaniu problemów współczesnego świata, lecz także jest skutecznym narzędziem dyplomatycznym - sprawdza się bowiem tam, gdzie tradycyjny formy stosunków dyplomatycznych są zbyt napięte lub w ogóle ich nie można nawiązać. ${ }^{32}$

Podsumowując powyższą charakterystyką dyplomacji naukowej (jako zjawiska i jako koncepcji badawczej) warto zwrócić uwagę, iż jakkolwiek nie ma ona jeszcze ugruntowanego statusu (zarówno w praktyce, jak i w teorii), to jego uzyskanie jest poniekąd tylko kwestią czasu. Ilościowy i jakościowy wzrost problemów międzynarodowych, które stają się przedmiotem polityki międzynarodowej i procesów dyplomatycznych, a których rozwiązanie jest jednak domeną postępów w wiedzy naukowej jest w ostatnim okresie bardzo wyraźny. Jednym z tego przykładów jest region Arktyki, który z powodu wielorakich następstw zmian klimatu oraz procesów globalizacji znacząco wzmocnił międzynarodowej znaczenie i stał się przedmiotem zainteresowania w skali globalnej. Jak zostanie to wskazane w kolejnej części artykułu region ten ma szczególne doświadczenia, jeżeli chodzi o międzynarodową współpracę naukową, a tym samym może odgrywać ważną rolę w kontekście rozwoju dyplomacji naukowej.

${ }^{30}$ V. Turekian, Building a National Science Diplomacy System, "Science \& Diplomacy" 2012, vol. 1, no. 4, dostępny on-line: http://www.sciencediplomacy.org/editorial/2012/buildingnational-science-diplomacy-system (20.03.2017).

${ }^{31}$ D. Copeland, op. cit.

32 Ibidem. 


\section{ARKTYKA JAKO OBSZAR STYKU POLITYKI MIĘDZYNARODOWEJ I NAUKI}

Obszary arktyczne od stuleci stanowiły przedmiot ciekawości mieszkańców Europy, którzy jednak stosunkowo powoli dokonywali eksploracji surowych, mroźnych i niebezpiecznych ziem oraz mórz Dalekiej Północy. Zdobywanie wiedzy przez Europejczyków na temat Arktyki dokonywało się najpierw „przy okazji" wypraw kolonizacyjnych (np. zamieszkanie Islandii i Grenlandii przez Wikingów odpowiednio w wieku IX i X), a nawet wypraw rybackich czy polowań wielorybników (np. odkrycie Nowej Ziemi w XI wieku czy niepotwierdzone odkrycie Spitsbergenu przez Pomorców w XIV lub XV wieku) ${ }^{33}$. Bardziej systematyczny kształt nabrało w czasach nowożytnych, gdy niektóre państwa zachodnioeuropejskie zmuszone ówczesną sytuacją geopolityczną (m.in. dominacja Hiszpanii i Portugali na oceanach), zaangażowały się w poszukiwania północnych szlaków morskich do Chin, zaś władcy Rosji zaczęli intensywny podbój Syberii ${ }^{34}$. Nie będzie przesadą stwierdzenie, iż ówcześni odkrywcy Arktyki dość często pełni role zarówno badaczy (mniej lub bardziej kompetentnych), jak też przedstawicieli ówczesnych władców europejskich, którzy byli wyposażani niekiedy w oficjalne bądź poufne instrukcje swych mocodawców (choć oczywiście nie można ich traktować jako dyplomatów). ${ }^{35}$

Odkrycia geograficzne na Dalekiej Północy ${ }^{36}$ w połączeniu z rozwojem wiedzy teoretycznej, sukcesywnie doskonalonymi technikami prowadzenia obserwacji oraz doświadczeń w ekstremalnych warunkach polarnych stymulowały rozwój badań naukowych realizowanych w Arktyce w wielu dziedzinach nauki mniej więcej od drugiej połowy XVII wieku. Jakkolwiek większość wypraw za północne koło podbiegunowe prowadzono $\mathrm{z}$ reguły pod flagami i w interesach poszczególnych państw europejskich, to w drugiej połowie XIX wieku rozwinęła się koncepcja współpracy międzynarodowej jako warunku sine qua non dalszego efektywnego rozwoju wiedzy na temat wielu zjawisk i procesów związanych z Arktyką, przede wszystkim w zakresie meteorologii. Miało to istotne znaczenie praktyczne dla rozwoju nawigacji oraz zrozumienia zjawisk klimatycznych półkuli północnej. Jej sztandarowym przykładem była inicjatywa K. Weyprechta organizowania skoordynowanych wypraw narodowych w celu zbadania Arktyki, zamiast ,wyścigu do bieguna". ${ }^{37}$ Zaproponowano wówczas szeroko zakrojony międzynarodowy program badawczy realizowany w ramach Międzynarodowego Roku Polarnego przez narodowe wyprawy i stacje badawcze (12 krajów). Warto podkreślić, iż miał on swoje kolejne edycje w latach: 1882/83, 1932/33, 1957/58 oraz 2007/8. ${ }^{38}$

${ }_{33}$ P. Urbańczyk, Zdobywcy Pótnocnego Atlantyku, Torun 2012.

${ }^{34}$ M. Łuszczuk, op. cit., s. 116.

${ }_{35}$ Zob. J. McCannon, A History of the Arctic. Nature, exploration and exploitation, London 2012.

${ }^{36}$ Zob. szerzej: H. Gurgul, Białe pustynie - Arktyka, Poznań 2002.

37 W. Barr, The Expeditions of the First International Polar Year 1882-83, Calgary 2008, s. 4.

${ }_{38}$ M. Łuszczuk, Międzynarodowa wspótpraca naukowa, [w:] M. Łuszczuk, P. Graczyk, A. Stępień, M. Śmieszek, Cele i narzędzia polskiej polityki arktycznej, Warszawa 2015, s. 92. 
Kolejnym czynnikiem wspierającym rozwój obserwacji i prac badawczych w europejskiej części Arktyki stał się Traktat Svalbardzki, pośrednio umożliwiający badania archipelagu przez badaczy z różnych państw. Wiele argumentów przemawia więc za tezą, iż współpraca naukowa dotycząca w Arktyce jest jednym z najdłużej rozwijanych i najważniejszych obszarów kooperacji międzynarodowej w tej części świata, włączając w to wiele inicjatyw o charakterze stricte eksploracyjno-sportowym (wyścig do bieguna północnego). Co interesujące, choć znaczenie prowadzenia badań (zwłaszcza meteorologicznych) w Arktyce wzrosło podczas II wojny światowej ${ }^{39}$, to jednak konflikt ten zapoczątkował - trwające w sumie przez całą zimną wojnę - osłabienie międzynarodowej współpracy naukowej (lub też jej ograniczenie poprzez powstanie barier polityczno-ideologicznych). Oczywiście, sytuacja ta była ściśle związana z rozwojem narodowych projektów badawczych realizowanych w Arktyce, a bardzo mocno ukierunkowanych na potrzeby bezpieczeństwa militarnego poszczególnych państw czy sojuszy. Wraz z zakończeniem zimnej wojny podporządkowanie nauki interesom państw nieco zelżało, choć oczywiście nie znikło, a jednocześnie bardzo poszerzył się zakres tematyczny prowadzonych badań.

$\mathrm{Z}$ uwagi na fakt, iż wiele obserwacji oraz badań prowadzonych w Arktyce dotyczy specyfiki oraz zmian środowiska naturalnego, które z definicji mają charakter transgraniczny (w rozumieniu prawno-międzynarodowym), to ich wyniki stanowiły i wciąż stanowią punkt wyjścia do pozanaukowych inicjatyw współpracy regionalnej. Najważniejszym tego przykładem był tzw. proces z Rovaniemi czyli implementacja „Strategii ochrony środowiska arktycznego" (Arctic Environmental Protection Strategy - AEPS) przyjętej w $1991 .{ }^{40}$ Współpraca ta po kilku latach została przekształcona w działalność Rady Arktycznej, która zostanie nieco bliżej przedstawiona w następnej części artykułu. ${ }^{41}$

Podstawową platformą wielonarodowej współpracy naukowej w Arktyce jest od ćwierćwiecza Międzynarodowy Komitet Badań Arktyki (IASC), który rozpoczął swoje prace w 1991 roku. Jest on organizacją pozarządową, której misją jest wspieranie i ułatwianie współpracy w zakresie badań, przez wszystkie kraje biorące udział w poznaniu każdego z rejonów Arktyki (obecnie IASC liczy 23 członków). IASC promuje i wspiera najistotniejsze interdyscyplinarne badania w celu lepszego poznania i zrozumienia regionu arktycznego oraz jego roli w systemie Ziemi. Do najważniejszych funkcji IASC należą: (a) zapewnianie obiektywnego i niezależnego doradztwa naukowego w kwestiach badań w Arktyce i przekazywanie istotnych informacji do publicznej wiadomości; (b) podej-

${ }^{39}$ K. Kubiak, Epizody „,Wojny o Pogode”": Niemieckie zalogowe stacje meteorologiczne w Arktyce 1941-1945, Zabrze -Tarnowskie Góry 2012.

${ }^{40}$ M. Tennberg, Arctic Environmental Cooperation. A study in governmentality, Rovaniemi 2000, dostępny on-line: https://lauda.ulapland.fi/bitstream/handle/10024/59450/Arctic_Environmental_Cooperation.pdf?sequ ence=1 (12.03.2017).

${ }^{4-}$ P. Graczyk, Rada Arktyczna jako główne forum wspótpracy w Arktyce [w:] Arktyka na początku XXI wieku. Między wspótpraca a rywalizacja, M. Łuszczuk (red.), Lublin 2013. 
mowanie działań służących ochronie, łatwiejszej wymianie i dostępności danych naukowych dotyczących Arktyki; (c) wspieranie międzynarodowego swobodnego dostępu naukowców do wszystkich obszarów geograficznych oraz dzielenie się wiedzą, zapleczem logistycznym oraz innymi zasobami. ${ }^{42}$

Bez wątpienia kooperacja naukowa w Arktyce w dobie intensywnych zmian klimatycznych odgrywa wyjątkową rolę, gdyż pozwala nie tylko na lepsze poznanie zachodzących procesów i zjawisk, lecz przede wszystkim stanowi podstawę do opracowywania propozycji adaptacji do nowej sytuacji. Jednocześnie jednak, badania w pewnych dziedzinach i obszarach mogą mieć szczególne znaczenie dla interesów społeczno-gospodarczych, politycznych czy też strategicznych poszczególnych państw z regionu i spoza jego granic. Dotyczy to np. poznania struktury dna morskiego i szelfu kontynentalnego Oceanu Arktycznego, prognozowanie ekstremalnych zjawisk pogodowych czy rozwijania nowoczesnych technologii o zastosowaniach zarówno cywilnych, jak i militarnych. Uwarunkowania te $\mathrm{z}$ jednej strony przyczyniają się do zwiększenia ilości prowadzonych międzynarodowych projektów badawczych, z drugiej zaś skłaniają państwa do aktywniejszego wykorzystywania wyników badań w swych politykach arktycznych, a więc de facto rozwijania dyplomacji naukowej. Jej zakres, charakter oraz przykłady są przedstawione i wyjaśnione w następnym podrozdziale.

\section{WYMIARY DYPLOMACJI NAUKOWEJ W ARKTYCE W XXI WIEKU}

Zgodnie z propozycją przedstawioną w części drugiej artykułu relacja między światem nauki a światem polityki w Arktyce może być rozpatrywana przez pryzmat koncepcji dyplomacji naukowej w ramach, której wyróżnia się jej trzy podstawowe wymiary.

\section{NAUKA W DYPLOMACJI}

Istotą relacji między badaczami a decydentami politycznymi oraz dyplomatami określanej jako „nauka w dyplomacji” jest wspieranie międzynarodowej działalności politycznej wiedzą naukową. Może one odnosić się zarówno do kwestii polityki zagranicznej (i tym samym służyć bezpośrednio i tylko interesom narodowym poszczególnych państw), jak też do mechanizmów współpracy międzynarodowej (a tym samym służyć wspólnym lub też podzielanym interesom grupy państwa). Pierwszą formułę ilustruje tzw. geologię polityczną w Arktyce ${ }^{43}$, drugą zaś uosabiają grupy robocze Rady Arktycznej.

${ }^{42}$ IASC, About IASC, dostępny on-line: http://iasc.info/iasc/about-iasc (18.03.2017).

${ }^{43}$ A. Makowski, Szelf kontynentalny Arktyki: źródło kryzysu czy wspótpracy międzynarodowej, [w:] Arktyka na początku..., s. 49. 
Przykładem „nauki w dyplomacji” jest fundamentalna rola badaczy w procesie implementacji postanowień Konwencji Narodów Zjednoczonych o Prawie Morza w zakresie wyznaczania granic szelfu kontynentalnego w Oceanie Arktycznym ${ }^{44}$. Warto w tym miejscu przypomnieć, iż pomimo, iż Stany Zjednoczone nie są stroną tej Konwencji, to wszystkie pięć państwa nadbrzeżnych Oceanu Arktycznego potwierdziło Deklaracją z Ilullisat z 28.05.2008 roku, iż zagadnienia eksploatacji i eksploracji zasobów morskich oraz dna mórz regionu arktycznego (a także kwestie żeglugi) są i będą regulowane na gruncie prawa międzynarodowego właśnie przez Konwencję o Prawie Morza i nie ma żadnej konieczności tworzenia nowych regulacji pod kątem regionu arktycznego. Zgodnie z treścią art. 76 Konwencji państwa nadbrzeżne dysponują prawem do zgłaszania roszczeń do szelfu arktycznego wychodzącego poza granice 200 milowej wyłącznej strefy ekonomicznej. Roszczenia te (zmierzające do ustalania zewnętrznej granicy szelfu) opierać się jednak muszą - zgodnie z przyjęta w Konwencji z Montego Bay tzw. formułą irlandzką - na kryteriach geomorfologicznych, takich jak podnóże zbocza kontynentalnego czy grubość skał osadowych..$^{45}$

Pomijając w tym miejscu szczegółowe kwestie związane z tą procedurą, które były już przedmiotem analiz naukowych ${ }^{46}$, należy wyraźnie podkreślić podstawą jakichkolwiek roszczeń jest przedstawienie argumentów o charakterze naukowym. Jak to stwierdził bardzo dobitnie J. Strandsbjerg: to nauka, a nie polityka decyduje obecnie o przebiegu granic w Arktyce, co sprawia, że procesy demarkacji szelfu w regionie mogą być mniej problematyczne, aniżeli jakiekolwiek inne rozstrzygnięcia $\mathrm{W}$ sferze geopolityki. ${ }^{47}$ Jakkolwiek to stanowisko wydaje się bardzo odstawać od rzeczywistej i prawnej sytuacji ${ }^{48}$, to nie zmienia to faktu, iż obecnie w trakcie rozpatrywania przez Komisję ds. Granic Szelfu Kontynentalnego są wnioski Rosji (złożony w sierpniu 2015 roku) oraz Danii (dotyczące

${ }^{44} \mathrm{Z}$ geologicznego punktu widzenia Arktyka leży na czterech tarczach kontynentalnych: kanadyjskiej, bałtyckiej, angarskiej i ałdańskiej, zaś jej centralną część zajmuje Ocean Arktyczny będący morzem ingresyjnym, które powstało w wyniku zalania zapadniętych obszarów lądu stałego. Podwodny Grzbiet Łomonosowa dzieli Ocean Arktyczny na dwa baseny: Euroazjatycki (basen Nansena, 4000-4500 m głębokości) i Północnoamerykański (basen Beauforta o głębokościach około $4000 \mathrm{~m}$ ). Drugi, lecz mniej wyraźny, Grzbiet Mendelejewa przebiega równolegle do Grzbietu Łomonosowa pomiędzy wyspami Ellesmere'a i Wrangla. Ocean Arktyczny ma ok., 14,4 mln km² powierzchni, przy czym w większości jest stosunkowo płytki: ok. 7 mln km² zajmują akweny szelfowe o głębokościach poniżej 500 metrów, co oznacza, że w dalszej przyszłości kopaliny znajdujące się pod jego dnem ewentualnie będą mogły być wydobywane za pomocą stosunkowo prostych platform wiertniczych. Za: Ibidem.

${ }^{45}$ Ibidem, s. 55.

${ }^{46}$ Zob. np. Ibidem; J. Symonides, Status prawny i roszczenia do Arktyki i do Bieguna Pótnocnego, „Państwo i Prawo” 2008, nr 1, s. 31-45.

47 J. Strandsbjerg, Cartography and Geopolitics in the Arctic Region, DIIS Working Paper 20, Copenhagen 2010.

48 Zob. P. Steinberg, The Truth About Politics and Cartography: Mapping Claims to the Arctic Seabed, "The Wire", 15.08.2015, dostępny on-line: https://thewire.in/2015/08/15/ the-truth-about-politics-and-cartography-...1 (15.09.2015). 
północnego szelfu grenlandzkiego złożony w grudniu 2014 roku), Kanada nadal prowadzi badania do swojego wniosku (złożony w grudniu 2014 roku), zaś Norwegia zakończyła procedurę w roku 2009. Jak widać w tym przypadku „nauki w dyplomacji" wiedza naukowa, a szczególnie wyniki specjalnie prowadzonych badań dna Oceanu Arktycznego są środkiem do zabezpieczenia interesów i zakresu terytorialnej jurysdykcji państwa nadbrzeżnych Oceanu Arktycznego.

Drugim z przykładów „nauki w dyplomacji” - tym razem odnoszącym się do poziomu międzynarodowego - jest działalność grup roboczych Rady Arktycznej, która została utworzona w 1996 roku jako forum współpracy międzyrządowej ośmiu państw, których terytoria położone są $\mathrm{w}$ graniach regionu (a więc na północ od północnego koła podbiegunowego). Mandat Rady Arktycznej obejmuje przede wszystkim zagadnienia ochrony środowiska naturalnego oraz zrównoważonego rozwoju w Arktyce. ${ }^{49}$

Zasadniczo w strukturze Rady Arktycznej wyróżnia się trzy poziomy. ${ }^{50}$ Poziom polityczny ma formę spotkań z udziałem ministrów - najczęściej odpowiedzialnych za sprawy zagranicznych. Poziom wykonawczy to spotkania dyplomatów w randze ambasadorów (w ostatnich latach określanych mianem ambasadorów arktycznych), czyli tzw. Senior Arctic Officials. Poziom roboczy Rady Arktycznej obejmuje działalność grup roboczych oraz coraz częściej powoływanych grup zadaniowych (tzw. task forces). W ocenie specjalistów „centralnym elementem" Rady Arktycznej jest sześć grup roboczych, które odpowiadają za większość projektów składających się na aktywność Rady. ${ }^{51}$ Do grona sześciu stałych grup roboczych Rady należą: Arctic Monitoring and Assessment Programme (AMAP), Protection of the Arctic Marine Environment (PAME), Conservation of Arctic Flora and Fauna (CAFF), Emergency Prevention Preparedness and Response (EPPR), Sustainable Development Working Group (SDWG) i Arctic Contaminants Action Program (ACAP).

„AMAP odpowiada za dostarczanie wiarygodnych i wyczerpujących informacji na temat stanu środowiska naturalnego Arktyki i jego zagrożeń oraz doradztwo naukowe na temat działań, jakie należy podjąć w celu wspierania rządów państw arktycznych w ich dążeniach do integracji działań naprawczych i zapobiegawczych dotyczących zanieczyszczeń i niepożądanych skutków zmian klimatu. Działalność PAME skupiona jest na kwestiach dotyczących ochrony i zrównoważonego użytkowania środowiska morskiego Arktyki. Ma szczególny mandat śledzenia adekwatności globalnych i regionalnych środków politycznych, prawnych $\mathrm{i}$ innych, oraz, $\mathrm{w}$ razie potrzeby, formułowania rekomendacji w kwestii ulepszeń. Współpraca w ramach CAFF dotyczy wymiany informacji na temat

49 P. Graczyk, Rada Arktyczna jako..., s. 321.

50 P. Graczyk, Observers in the Arctic Council-evolution and prospects, ,The Yearbook of Polar Law" 2011, vol. 3, s. 590-591.

51 P. Graczyk et al., Zarządzanie regionem i międzynarodowa wspólpraca polityczna, [w:] Cele i narzędzia..., s. 55. 
technik zarządzania i systemów regulacyjnych w kwestii bioróżnorodności oraz ułatwienia podejmowania decyzji na podstawie istniejącej wiedzy. Zapewnia ona także mechanizm rozwijania wspólnych odpowiedzi na kwestie ważne dla ekosystemu Arktyki, takie jak rozwój ekonomiczny, możliwości ochrony i zobowiązania polityczne. EPPR zajmuje się różnymi aspektami zapobiegania, gotowości i reagowania w środowiskowych sytuacjach kryzysowych na obszarze Arktyki. Stanowi mechanizm wymiany informacji na temat najlepszych praktyk i prowadzenia projektów obejmujących rozwój doradztwa oraz metodologii oceny ryzyka, ćwiczenia reagowania kryzysowego i szkoleń. Celem EPPR jest przyczynienie się do ochrony środowiska Arktyki przed niebezpieczeństwem lub wpływem przypadkowego uwolnienia zanieczyszczeń lub radionuklidów. Mandat grupy obejmuje również kwestie związane ze skutkami klęsk żywiołowych. SDWG proponuje i realizuje projekty, które dostarczają wiedzy praktycznej i przyczyniają się do postępu w dziedzinie zrównoważonego rozwoju Arktyki. Projekty te dotyczą ochrony środowiska naturalnego i wzmocnienia lokalnych gospodarek, kultury oraz zdrowia ludności rdzennej oraz mieszkańców Arktyki. Celem współpracy w ramach grupy jest poprawa środowiskowych, gospodarczych i społecznych warunków życia ogółu mieszkańców Arktyki. ACAP pracuje nad zmniejszeniem emisji zanieczyszczeń środowiskowych w ramach zidentyfikowanych obszarów ryzyka. Odbywa się to przez proponowanie rządom państw arktycznych naprawczych i zapobiegawczych działań wewnętrznych dotyczących emisji zanieczyszczeń. Grupa stanowi mechanizm wzmacniający wewnętrzne działania w celu redukcji emisji i innych uwolnień zanieczyszczeń". ${ }^{52}$

Między innymi z uwagi na fakt, iż jednomyślność jest główną zasadą podejmowania decyzji Rady Arktycznej (i to na wszystkich poziomach współpracy oraz $\mathrm{w}$ odniesieniu do wszystkich rodzajów spotkań), to proces podejmowania decyzji w jej ramach jest dość złożony. Należy uznać, iż w zasadzie Rada działa na podstawie inicjatywy oddolnej, co oznacza, że jej projekty i działania są z reguły proponowane na poziomie grup roboczych. To tutaj zbierane $\mathrm{i}$ analizowane są niezbędne informacje oraz dane naukowe. Tutaj też odbywają się kluczowe debaty, w których uczestniczą delegowani przez państwa arktyczne (oraz obserwatorów) naukowcy oraz badacze i eksperci z różnych agend rządowych. ${ }^{53}$

Warto podkreślić, iż „udział w pracach i projektach grup pozwala nie tylko na dostęp do danych naukowych oraz dzielenie się nimi, ale również na kształtowanie ewentualnych rekomendacji politycznych dla rządów państw arktycznych" ${ }^{54} \mathrm{Co}$ więcej, ,kontakty między naukowcami i specjalistami, zawiązane oraz umocnione w specyficznym, nieformalnym środowisku grup roboczych, mogą mieć znaczne przełożenie na współpracę bilateralną lub w innych instytucjach międzynaro-

\footnotetext{
${ }^{52}$ Ibidem, s. 55-56.

53 Ibidem, s. 56.

${ }^{54}$ Ibidem, s. 57.
} 
dowych, jak również w ramach innych projektów naukowych”. ${ }^{55}$ „W systemie trzypoziomowego konsensu w RA, ten osiągany na poziomie eksperckim grup roboczych ma najszerszy zakres i w najmniejszym stopniu podlega ocenie politycznej" ${ }^{56}$, jednak bez wątpienia pełni kluczową rolę, jeżeli chodzi o merytoryczny wymiar prac Rady Arktycznej.

Kończąc tą krótką prezentację funkcjonowania Rady Arktycznej w kontekście dyplomacji naukowej warto zaznaczyć, iż również dyplomaci w Radzie Arktycznej - szczególnie na poziomie SAO - muszą się wykazać odpowiednim kompetencjami w zakresie analiz oraz oceny treści dokumentów opracowywanych przez badaczy i ekspertów ${ }^{57}$. Jak to określił P. Graczyk, pełnią oni rolę „łączników" między grupami roboczymi, a zatem przekładają efekty prac naukowych na cele polityczne wytyczane przez ministrów. ${ }^{58}$

\section{DYPLOMACJA DLA NAUKI}

Drugim wymiarem dyplomacji naukowej są działania dyplomatyczne zmierzające do wspierania aktywności naukowo-badawczej. Przykładami takich sytuacji w odniesieniu do Arktyki są: (1) konferencja ministrów nauki z państw (oraz przedstawiciela Unii Europejskiej) zaangażowanych w badania arktyczne zorganizowana w Waszyngtonie 28.09.2917 oraz (2) wynegocjowanie oraz podpisanie międzyrządowej umowy państw arktycznych: Agreement on Enhancing International Arctic Scientific Cooperation (Porozumienie w sprawie wzmocnienia międzynarodowej współpracy naukowej na Arktyce). ${ }^{59}$ Oba te przykłady choć dotyczą tej samej materii, a więc ustalenia możliwości rozwoju międzynarodowej współpracy naukowej w Arktyce, to różnią się swoim zakresem oraz znaczeniem prawno-międzynarodowym.

Konferencja, zwana jako White House Arctic Science Ministerial, została zorganizowana przez administrację prezydenta B. Obamy 28 września 2016 roku, czyli w ostatnich miesiącach jego drugiej kadencji, a jednocześnie w ostatnich

${ }^{55}$ Ibidem, s. 57.

56 Ibidem, s. 57.

57 „Do podstawowych zadań SAOs należą koordynacja, prowadzenie (guide) i monitorowanie prac grup roboczych, grup zadaniowych oraz innych pomocniczych i uzupełniających ciał w zgodzie z decyzjami i instrukcjami otrzymanymi od ministrów. Ponadto, mogą oni dokonywać przeglądu i oceny propozycji i inicjatyw przedłożonych przez państwa arktyczne i Stałych Przedstawicieli (reprezentujący ludy rdzenne Arktyki) oraz przedstawiać odpowiednie rekomendacje ministrom". P. Graczyk, Rada Arktyczna jako..., s. 321

58 Ibidem, s. 327.

59 Arctic Council, Arctic Council Ministers meet, sign binding agreement on science cooperation, pass Chairmanship from U.S. to Finland, 13.05.2017, dostępny on-line: http://www. arctic-council.org/ index.php/en/our-work2/8-news-and-events/451-fairbanks-04 (15.05.2017). 
miesiącach przewodnictwa USA w Radzie Arktycznej. ${ }^{60}$ Prace nad przygotowaniem spotkania (a dokładnie to jego rezultatów) miały dwa główne wymiary: polityczny, czyli opracowanie Deklaracji Ministrów oraz naukowy polegający na opracowanie katalogu projektów międzynarodowych już realizowanych w Arktyce, a mogących pełnić rolę ram dla dalszego rozwoju badań. Katalog ten obejmował cztery obszary tematyczne:

1) znaczenie arktycznych badań naukowych w skali regionalnej i globalnej;

2) rozwijanie, integracja obserwacji naukowych w Arktyce i dzielenie się ich wynikami;

3) wykorzystanie rezultatów badań naukowych w rozwiązywaniu problemów lokalnych Arktyki, a także w kształtowaniu strategii globalnych w odpowiedzi na zmiany klimatu;

4) znaczenie badań polarnych w rozwoju edukacji w dziedzinie nauk przyrodniczych, inżynierii, techniki i matematyki (STEM) oraz zwiększenia zaangażowania zwykłych obywateli w procesy badawcze.

Samo spotkanie w Waszyngtonie przebiegło bez większych kontrowersji, choć warto zauważyć, iż wyraźnie wybrzmiały na nim głosy przedstawicieli arktycznych ludów rdzennych, które oczekują większego współudziału w badaniu Arktyki, jak też respektowania ich praw podczas prowadzonych badań. Wśród wielu wygłoszonych przemówień (każdy z przedstawicieli 25 państw miał 5-7 minut na przedstawienie swego stanowiska) przewijała się kwestia konieczności zwrócenia uwagi na globalny wymiar zmian zachodzących w Arktyce. Wszystkie państwa oraz Unia Europejska z równym zaangażowaniem poparły konieczność dalszych prac nad konkretyzacją zakresu współpracy i osiąganiu opartego na niej efektu synergii. ${ }^{61}$

W ocenie obserwatorów konferencja w Białym Domu zwracając uwagę na konsekwencje zmian klimatycznych obserwowanych w Arktyce istotnie przyczyniła się do podniesienia rangi badań w Arktyce. ${ }^{62}$ Pozwoliła również na zebranie informacji o realizowanych już krajowych i międzynarodowych projektach, a tym samym określiła istniejące luki w wiedzy na temat Arktyki i zarysowała perspektywy dalszego jej rozwoju. Oczywiście stroną merytoryczną rezultatów konferencji zarządzali sami badacze lub osoby odpowiedzialne za organizację ba-

${ }^{60}$ The White House Office of the Press Secretary, Fact Sheet: United States Hosts FirstEver Arctic Science Ministerial to Advance International Research Efforts, Washington, D.C., 28.09.2016, dostępny on-line: https://obamawhitehouse.archives.gov/the-press-office/2016/09/28/ fact-sheet-united-states-hosts-first-ever-arctic-science-ministerial (30.04.2017).

${ }_{61}$ M. Łuszczuk, Informacja na temat spotkania Ministrów Nauki w sprawie badań arktycznych (Waszyngton, USA, 28 września 2016), Polskie Konsorcjum Polarne - aktualności, 28.10.2017, dostępny on-line: http://www.pkpolar.pl/konsorcjum/informacja-na-temat-spotkania-ministrow-nauki-w-sprawie-badan-arktycznych-waszyngton-d-c-usa-28-wrzesnia-2016/ (30.04.2017).

${ }^{62}$ K. Stephen, A Legacy of Science Cooperation for Future Generations: The White House Arctic Science Ministerial, The Arctic Institute, 26.10.2016, dostępny on-line: http://www.thearcticinstitute.org/white-house-arctic-science-ministerial/ (30.04.2017). 
dań polarnych w poszczególnych państwach. Na podstawie ustaleń poczynionych w Waszyngtonie jesienią 2018 roku odbędzie się kolejne spotkanie ministrów nauki zainteresowanych badaniami w Arktyce, tym razem w Europie.

Drugim przykładem aktywności, którą można zakwalifikować jako dyplomację dla nauki stanowiły prace nad przyjęciem oraz podpisanie Porozumienia w sprawie wzmocnienia międzynarodowej współpracy naukowej na Arktyce. Prace te prowadziła utworzona w ramach Rady Arktycznej na podstawie Deklaracji z Kiruny (maj 2013) tzw. Grupa Zadaniowa ds. Współpracy Naukowej (Scientific Cooperation Task Force - SCTF). Jej celem było wypracowanie pod auspicjami Rady Arktycznej prawnie wiążącego międzynarodowego porozumienia dotyczącego rozwoju i ułatwienia współpracy naukowo-badawczej pomiędzy państwami arktycznymi, a szczególnie jej wymiaru organizacyjnego, udostępniania danych i wyników badań, dostępu do infrastruktury naukowej i logistycznej, uproszczenia zasad prowadzenia badań transgranicznych w terenie (przemieszczania się osób, sprzętu i próbek), jak też udziału aktorów niearktycznych i ich roli w badaniach nad Arktyką ${ }^{63}$ Prace podjęto w grudniu 2013, a zakończono w lipcu 2016 roku; porozumienie zostało oficjalnie podpisane na spotkaniu ministrów spraw zagranicznych państw arktycznych w Fairbanks 11.05.2017 roku. ${ }^{64}$ Analiza treści wyraźnie wskazuje, iż jest ono dokumentem zmierzającym do ustalenia $\mathrm{w}$ miarę jednolitych regionalnych reguł i norm w zakresie organizowania prac badawczych na obszarze Arktyki. Jakkolwiek cel ten udało się osiągnąć, to kwestią nadal otwartą pozostaje sposób implementacji porozumienia, szczególnie w odniesieniu do badaczy pochodzących z państw niearktycznych. ${ }^{65}$ Niezależnie od tej kwestii, porozumienie stanowi przykład efektów prac dyplomatycznych, które po akceptacji politycznej ze strony władz państw arktycznych będą wpływać na możliwości rozwoju współpracy naukowej w Arktyce.

\section{NAUKA DLA DYPLOMACJI}

Ostatnim wymiarem dyplomacji naukowej są działania polegające na traktowaniu kooperacji naukowej badaczy pochodzących z różnych państwa, jako okazji czy też platformy wymiany poglądów, budowy wzajemnego zrozumienia i zaufania oraz - w wyjątkowych sytuacjach - jedynego kanału bezpośrednich kontaktów międzypaństwowych.

W tym kontekście warto zwrócić uwagę, na fakt, iż generalnie Arktyka, a szczególnie Rada Arktyczna, były i są nadal postrzegane jako jedno z niewielu miejsc pod-

63 Arctic Council, Task Force on Scientific Cooperation meets in Ottawa, 26.07.2016, dostępny on-line: http://www.arctic-council.org/index.php/en/our-work2/8-news-and-events/408sctf-ottawa-july-2016 (19.05.2017).

${ }^{64}$ Arctic Council, Arctic Council Ministers meet, sign binding agreement...

${ }^{65}$ A. Shibata, M. Raita, An Agreement on Enhancing International Arctic Scientific Cooperation: Only for the Eight Arctic States and Their Scientists?, "The Yearbook of Polar Law" 2016, vol. 8, s. 129-162. 
trzymywania pozytywnych relacji pomiędzy państwami Zachodu a Rosją w okresie tzw. kryzysu ukraińskiego. ${ }^{66}$ Pomimo formułowanych niekiedy w mediach opinii, iż po aneksji Krymu przez Rosję, kolejnym jej celem ekspansji mogą stać się obszary arktyczne $^{67}$, rzeczywistość okazuje się dużo bardziej pokojowa i przewidywalna. $\mathrm{O}$ ile jeszcze podczas przewodnictwa Kanady w Radzie Arktycznej pojawiła się kwestia czy arktyczne państwa Zachodu nie powinny zerwać współpracy z Rosją na forum Rady ${ }^{68}$, to już podczas przewodnictwa USA (2015-2017) temat ten w zasadzie się już nie pojawił. Co więcej kontynuacja współpracy naukowej w grupach roboczych, grupach zadaniowych Rady Arktycznej była rozszerzona na nowe obszary, w tym jesienią 2015 na wrażliwą pod względem bezpieczeństwa militarnego i niemilitarnego współpracę arktycznych straży wybrzeża. ${ }^{69}$ Jakkolwiek przed 2014 rokiem „,nauka dla dyplomacji” wydawała się nie mieć zastosowania w regionie Arktyki od czasu zakończenia zimnej wojny, to jednocześnie nie sposób dziś zanegować oceny, iż to właśnie wyjątkowość wieloletniej kooperacji w Arktyce opartej na współpracy naukowej, pozwoliła (jak dotąd) „ochronić” region przed politycznymi konsekwencjami kryzysu ukraińskiego. ${ }^{70}$

\section{PODSUMOWANIE}

Wzrost liczby problemów o charakterze transgranicznym związanych z konsekwencjami zmian klimatu, bezpieczeństwa międzynarodowego czy ochrony środowiska sprawa, iż współczesne stosunki międzynarodowe bardziej niż kiedykolwiek wcześniej wymagają bardziej otwartego podejścia do współpracy i komunikacji, a także innowacyjnych rozwiązań w sferze polityki zagranicznej. Odpowiedzią na tą sytuację jest między innymi rozwój nowych form kooperacji między światem polityki międzynarodowej i zagranicznej, a zwłaszcza dyploma-

${ }^{66}$ M.R. Olesen, After Ukraine: Keeping the Arctic Stable, DIIS Policy Brief, 29.09.2014, dostępny on-line: https://www.diis.dk/en/research/after-ukraine-keeping-the-arctic-stable (22.03.2017).

${ }^{67}$ A. Watts, Could the Arctic Circle Become the Next Crimea? 26.10.2016, dostępny on-line: http://georgetownsecuritystudiesreview.org/2016/11/06/could-the-arctic-circle-become-the-next-crimea/ (23.03.2017).

${ }^{68}$ Najbardziej wyraźną manifestacją popierającą to stanowisko była absencja Kanady na jednym ze spotkań Rady Arktycznej organizowanym w Moskwie w kwietniu 2014 roku, zob. T. Pettersen, Canada skips Arctic Council meeting over Ukraine, BarentsObserver.com, 16.04.2014, dostępny on-line: http://barentsobserver.com/en/arctic/2014/04/canada-skips-arctic-council-meeting-over-ukraine-16-04 (23.04.2017).

69 A. Östhagen, The Arctic Coast Guard Forum: Big Tasks, Small Solutions, The Arctic Institute, 2.11. 2015, dostępny on-line: http://www.thearcticinstitute.org/the-arctic-coast-guard-forumbig-tasks/ (30.03.2017).

${ }^{70}$ Por. P.A. Berkman, Stability and Peace in the Arctic Ocean through Science Diplomacy, "Science \& Diplomacy" 2014, vol. 3, no. 2, dostępny on-line: http://www.sciencediplomacy.org/ files/stability_and_peace_in_the_arctic_ocean_through_science_diplomacy_science_diplomacy.pdf (18.05.2016). 
cją oraz światem nauki. Choć oba te światy sporo dzieli czy też różni, to jednocześnie niektóre z ich funkcji czy cech są zbieżne, co stanowi jedną z kluczowych przesłanek zjawiska dyplomacji naukowej. Ta odmiana dyplomacji sama w sobie jest dość zróżnicowana, co dość wyraźnie wskazuje zarówno praktyka, jak też kształtowana od niedawna koncepcja dyplomacji naukowej.

Jakkolwiek sfera kooperacji naukowców i dyplomatów obejmuje różne aspekty i formy aktywności, to z pewnością próby jej dekonstrukcji oraz analizy stanowić mogą ważne źródło wiedzy nie tylko z zakresu nauki o stosunkach międzynarodowych, lecz potencjalnie także źródło inspiracji dla praktyków zarówno naukowców, jak i dyplomatów. Jak wskazują badania dotyczące postaw uczestników dyplomacji naukowej ${ }^{71}$ istnieją pewne rozbieżności w ich oczekiwaniach oraz ocenach rezultatów wspólnych przedsięwzięć. Aby zredukować tego typu napięcia czy niepewności warto wyraźnie podkreślić dwuwymiarowy charakter dyplomacji naukowej, co w tym artykule starano się zaznaczyć. Dyplomacja naukowa to zarówno narzędzie realizacji celów polityki zagranicznej państwa, jak też aktywność w istotny sposób wspierająca współpracę na poziomie ponadnarodowym. Nieco paradoksalnie te dwa wymiary się dopełniają, co sprawia, iż dyplomacja naukowa jako praktyka ma istotny potencjał dla rozwoju stosunków międzynarodowych, a jako koncepcja może w wartościowy sposób pomóc wyjaśnić zachowania państwa na arenie międzynarodowej.

Zjawisko dyplomacji naukowej w Arktyce - jak starano się wykazać - także odznacza się wspomnianą dwuwymiarowością. Może być ona w związku z tym traktowana jako przejaw tzw. soft power, ${ }^{72}$ jak również jako platforma międzynarodowej kooperacji polityczno-naukowej. W tym zakresie Arktyka, być może po raz kolejny, może odegrać rolę ,,poligonu” na którym państwa oraz inni uczestnicy stosunków międzynarodowych będą mogli sprawdzać, jakie są optymalne formy ich relacji, które mechanizmy są bardziej lub też mniej efektywne. Rodzi się jednak także pytanie $\mathrm{w}$ jakim stopniu efekt synergii generowany przez dyplomacje naukową może okazać się niekorzystny dla któregoś lub jednocześnie obu z jej uczestników? Z jednej strony pojawiają się już przecież głosy zawiedziony naukowców, iż nie są rozumiani przez polityków, że ich odkrycia są lekceważone. $\mathrm{Z}$ drugiej strony decydenci polityczni mają zastrzeżenia do brak jednoznacznych stanowisk, zbyt zawiłych wywodów czy też zawodnych modeli. Mając to na uwadze można stwierdzić, iż dyplomacja naukowa prawdopodobnie pozostanie zjawiskiem opartym na dynamicznej interakcji oraz trudnej komunikacji między dwoma sferami: nauką a polityką ${ }^{73}$.

${ }^{71}$ T. Flink, U. Schreiterer, op. cit.

${ }^{72}$ R.G. Bertelsen, L. Xing, M.H. Gregersen, Chinese Arctic science diplomacy. An instrument for achieveing the Chinese dream? [w:] Global Challenges in the Arctic Region: Sovereignty, Environment and Geopolitical Balance, E. Conde, S. Iglesias Sánchez (eds), New York 2016, s. $442-460$.

${ }^{73}$ T. Skodvin, Science-policy interaction in the global greenhouse: Institutional design and institutional performance in the Intergovernmental Panel on Climate Change (IPCC), CI- 
Uwzględniając powyższe wnioski oraz obserwacje warto zwrócić uwagę, iż badawcza użyteczność koncepcji dyplomacji naukowej może się rozwijać dwutorowo. Po pierwsze, poprzez dalsze badanie jej specyfiki oraz rezultatów na płaszczyźnie międzynarodowej (co zostało podjęte w tym opracowaniu). Po drugie zaś, poprzez badanie jej głębszych uwarunkowań odnoszących się nie tylko do sfery praktycznych rozwiązań przyjmowanych w poszczególnych państwach, lecz także poprzez rekonceptualizację relacji między wiedzą a władzą w obliczu nowych wyzwań społecznych, gospodarczych i ekologicznych z jakimi mierzy się obecnie społeczność międzynarodowa.

Title: Science diplomacy as a form of cooperation and rivalry in the Arctic.

Summary: In the context of the challenges posed by the intensifying effects of climate change and the growing international importance of the Arctic, the question about relationship between scientists and diplomats and political decision-makers in process of shaping and implementing foreign policy has been emerging. This article - based on the concept of scientific diplomacy and analysis of selected examples of interactions between the world of science and world of foreign policy in the Arctic region - indicates the two-dimensional nature of a scientific diplomacy. On the one hand, there is a national dimension - oriented towards the realization of state's own interests and on the other there is an international dimension oriented towards developing regional cooperation and solving common problems. This specific nature of scientific diplomacy means that it can be perceived both as a instrument of rivalry and a mechanism of cooperation in contemporary international relations.

Keywords: scientific diplomacy, diplomacy, international scientific cooperation, Arctic

\section{BIBLIOGRAFIA}

1. AMERICAN ASSOCIATION FOR THE ADVANCEMENT OF SCIENCE, Center for Science Diplomacy, 2017: dostępny on-line: https://www.aaas.org/program/center-science-diplomacy (20.03.2017)

2. ARCTIC COUNCIL, 2016: Task Force on Scientific Cooperation meets in Ottawa, dostępny on-line: http://www.arctic-council.org/index.php/en/our-work2/8-news-and-events/408-sctf -ottawa-july-2016 (19.05.2017)

3. ARCTIC COUNCIL, 2017: Arctic Council Ministers meet, sign binding agreement on science cooperation, pass Chairmanship from U.S. to Finland, dostępny on-line: http://www.arctic-council.org/ index.php/en/our-work2/8-news-and-events/451-fairbanks-04 (15.05.2017).

4. BARR W., 2008: The Expeditions of the First International Polar Year 1882-83, Calgary.

5. BARSTON, R.P., 2013: Modern diplomacy, 4th edition, London.

6. BERKMAN P.A., 2014: Stability and Peace in the Arctic Ocean through Science Diplomacy, "Science \& Diplomacy", vol. 3, no. 2, dostępny on-line: http:/www.sciencediplomacy.org/files/ stability_and_peace_in_the_arctic_ocean_through_science_diplomacy_science_diplomacy. $\operatorname{pdf}(18.05 .2016)$.

CERO Working Paper 1999:3, dostęny on-line: https://brage.bibsys.no/xmlui/bitstream/handle/ 11250/192440/CICERO_Working_Paper_1999-03.pdf?sequence=1 (16.04.2017). 
7. BERTELSEN R.G., XING L., GREGERSEN M.H., 2016: Chinese Arctic science diplomacy. An instrument for achieveing the Chinese dream?W: Global Challenges in the Arctic Region: Sovereignty, Environment and Geopolitical Balance, E. Conde, S. Iglesias Sánchez (eds), New York.

8. BOGDÓŁ-BRZEZIŃSKA A., 2012: Międzynarodowe struktury wiedzy i innowacji - mechanizmy zmiany, aktualne trendy i uczestnicy. W: Geoekonomia, A. Aleksy-Szucsich, E. Haliżak (red.), Warszawa.

9. COMMITTEE ON GLOBAL SCIENCE POLICY AND SCIENCE DIPLOMACY, NATIONAL RESEARCH COUNCIL, 2012: U.S. and International Perspectives on Global Science Policy and Science Diplomacy: Report of a Workshop, Washington, D.C., dostępny on-line: https:// www.nap.edu/login.php? record_id=13300\&page=https\%3A\%2F\%2Fwww.nap.edu\%2Fdownload\%2F13300 (20.02.2017).

10. COPELAND D., 2016: Science Diplomacy,W: The SAGE Handbook of Diplomacy, C. M. Constantinou, P. Kerr, P. Sharp (eds), London.

11. CZARNY R.M., 2015: The High North. Between Geography and Politics, Heidelberg.

12. FLINK T., SCHREITERER U., Science diplomacy at the intersection of $S \& T$ policies and foreign affairs: toward a typology of national approaches. „Science and Public Policy” 2010, vol. 27, nr 9, s. 665-677.

13. GRACZYK P., 2011: Observers in the Arctic Council - evolution and prospects, „The Yearbook of Polar Law", vol. 3, s. 590-591.

14. GRACZYK P., 2013: Rada Arktyczna jako główne forum wspótpracy w Arktyce. W: Arktyka na początku XXI wieku. Między wspótpraca a rywalizacja, M. Łuszczuk (red.), Lublin.

15. GRACZYK P., et al., 2015: Zarzadzanie regionem i międzynarodowa wspótpraca polityczna. W: M. Łuszczuk, P. Graczyk, A. Stępień, M. Śmieszek, Cele i narzędzia polskiej polityki arktycznej, Warszawa.

16. GURGUL H., 2002: Białe pustynie - Arktyka, Poznań.

17. HALIŻAK E., 1988a: Wspólpraca naukowo-techniczna Wschód-Zachód, Warszawa.

18. HALIŻAK E., 1988b: Międzynarodowe stosunki naukowo-techniczne i zagraniczna polityka naukowo-techniczna. W: Zmienność i instytucjonalizacja stosunków międzynarodowych, J. Kukułka (red.), Warszawa.

19. HALIŻAK E., 1991: Internacjonalizacja nauki i techniki. W: Internacjonalizacja życia narodów i państw, J. Kukułka (red.), Warszawa.

20. HOCKING B., 1999: Catalytic Diplomacy. W: Innovation in Diplomatic Practice, J. Melissen (ed), Basingstoke.

21. IASC, 2017: About IASC, dostępny on-line: http://iasc.info/iasc/about-iasc (18.03.2017).

22. KUBIAK K., 2012: Epizody „,Wojny o Pogodę”: Niemieckie załogowe stacje meteorologiczne w Arktyce 1941-1945, Zabrze -Tarnowskie Góry.

23. LENGENHOVE van L., 2016: Science Diplomacy: New Global Challenges, New Trend, RSIS Commentary No-082-12, dostępny on-line: https:/www.rsis.edu.sg/wp-content/uploads/2016/04/CO16082.pdf (23.02.2017).

24. ŁOŚ-NOWAK, T., 2011: O potrzebie rekonstrukcji przestrzeni badawczej w nauce o stosunkach międzynarodowych. Refleksje natury polityczno-normatywnej, systemowej i metaforycznej, „Przegląd Politologiczny” 2011, tom XVI, nr 1, s. 25-38.

25. ŁUSZCZUK M., 2015: Ewolucja ról międzynarodowych w regionie Arktyki, Lublin.

26. ŁUSZCZUK M., 2015: Międzynarodowa wspótpraca naukowa. W: M. Łuszczuk, P. Graczyk, A. Stępień, M. Śmieszek, Cele i narzędzia polskiej polityki arktycznej, Warszawa.

27. ŁUSZCZUK M., 2016: Informacja na temat spotkania Ministrów Nauki w sprawie badań arktycznych (Waszyngton, USA, 28 września 2016), Polskie Konsorcjum Polarne - aktualności, 
dostępny on-line: http://www.pkpolar.pl/konsorcjum/informacja-na-temat-spotkania-ministrow -nauki-w-sprawie-badan-arktycznych-waszyngton-d-c-usa-28-wrzesnia-2016/ (30.04.2017).

28. MAKOWSKI A., 2013: Szelf kontynentalny Arktyki: źródto kryzysu czy wspótpracy międzynarodowej. W: Arktyka na początku XXI wieku. Między wspólpraca a rywalizacja, M. Łuszczuk (red.), Lublin.

29. MARZĘDA K., PIETRAŚ M. (red) 2008: Późnowestfalski ład międzynarodowy, Lublin.

30. MCCANNON J., 2012: A History of the Arctic. Nature, exploration and exploitation, London.

31. NYE, J.S. 2007: Soft power: jak osiagnać sukces w polityce światowej, Warszawa.

32. OLESEN M.R., 2014: After Ukraine: Keeping the Arctic Stable, DIIS Policy Brief, dostępny on-line: https://www.diis.dk/en/research/after-ukraine-keeping-the-arctic-stable (22.03.2017).

33. ÖSTHAGEN A., 2015: The Arctic Coast Guard Forum: Big Tasks, Small Solutions, The Arctic Institute, dostępny on-line: http://www.thearcticinstitute.org/the-arctic-coast-guard-forum-big -tasks/ (30.03.2017).

34. PETTERSEN T., 2014: Canada skips Arctic Council meeting over Ukraine, BarentsObserver. com, dostępny on-line: http://barentsobserver.com/en/arctic/2014/04/canada-skips-arctic-council-meeting-over-ukraine-16-04 (23.04.2017).

35. PIETRAŚ M., 2015: Przestrzeń badawcza nauki o stosunkach międzynarodowych, „Politeja”, vol. 36, tom 5, s. 65-97.

36. SHIBATA A., RAITA M., 2016: An Agreement on Enhancing International Arctic Scientific Cooperation: Only for the Eight Arctic States and Their Scientists?, "The Yearbook of Polar Law", vol. 8, s. 129-162.

37. SKODVIN T., 1999: Science-policy interaction in the global greenhouse: Institutional design and institutional performance in the Intergovernmental Panel on Climate Change (IPCC), CICERO Working Paper 3, dostęny on-line: https://brage.bibsys.no/xmlui/bitstream/handle/11250/192440/CICERO_Working_Paper_1999-03.pdf? sequence=1 (16.04.2017).

38. SKOLNIKOFF E., 1992: The elusive transformation. Science, technology, and the evolution of international politics, Princeton.

39. SNOW N., Taylor, Ph.M. (eds),2009: Routledge Handbook of Public Diplomacy, London.

40. STEINBERG P., 2015: The Truth About Politics and Cartography: Mapping Claims to the Arctic Seabed, "The Wire",dostępny on-line: https://thewire.in/2015/08/15/the-truth-about-politics-and-cartography-...1 (15.09.2015).

41. STEPHEN K., 2016: A Legacy of Science Cooperation for Future Generations: The White House Arctic Science Ministerial, The Arctic Institute, dostępny on-line: http://www.thearcticinstitute.org/white-house-arctic-science-ministerial/ (30.04.2017).

42. STRANDSBJERG J., 2010: Cartography and Geopolitics in the Arctic Region, DIIS Working Paper 20, Copenhagen.

43. SURMACZ B. (red.), 2013: Nowe oblicza dyplomacji, Lublin.

44. SURMACZ B., 2015: Ewolucja wspótczesnej dyplomacji, Lublin.

45. SYMONIDES J., 2008: Status prawny i roszczenia do Arktyki i do Bieguna Pótnocnego, „Państwo i Prawo", nr 1, s. 31-45.

46. TENNBERG M., 2000: Arctic Environmental Cooperation. A study in governmentality, Rovaniemi, dostępny on-line: https://lauda.ulapland.fi/bitstream/handle/10024/59450/Arctic_Environmental_Cooperation.pdf? sequence $=1$ (12.03.2017).

47. THE ROYAL SOCIETY, 2010: New frontiers in science diplomacy, London, dostęny on-line: https://royalsociety.org/ topics-policy/publications/2010/new-frontiers-science-diplomacy/ (15.03.2017). 
48. TUREKIAN V., 2012: Building a National Science Diplomacy System, "Science \& Diplomacy", vol. 1, no. 4, dostępny on-line: http://www.sciencediplomacy.org/editorial/2012/building-national-science-diplomacy-system (20.03.2017).

49. TUREKIAN V., et al, 2014: The Emergence of Science Diplomacy. W: Science Diplomacy. New Day or False Dawn?, L. Davis, R. Patman (eds), London.

50. URBAŃCZYK P., 2012: Zdobywcy Pótnocnego Atlantyku, Toruń.

51. WAGNER C.S., 2002: Science and foreign policy, The elusive partnership: science and foreign policy, "Science and Public Policy" 2002, vol. 29, nr 6, s. 409-417.

52. WATTS A., 2016: Could the Arctic Circle Become the Next Crimea?, dostępny on-line: http:// georgetownsecuritystudiesreview.org/2016/11/06/could-the-arctic-circle-become-the-next-crimea/ (23.03.2017).

53. THE WHITE HOUSE OFFICE OF THE PRESS SECRETARY, 2016: Fact Sheet: United States Hosts First-Ever Arctic Science Ministerial to Advance International Research Efforts, Washington, D.C., dostępny on-line: https://obamawhitehouse.archives.gov/the-press-office/2016/09/28/ fact-sheet-united-states-hosts-first-ever-arctic-science-ministerial (30.04.2017).

54. WOJCIUK A., 2010: Dylematy potęgi. Praktyczna teoria stosunków międzynarodowych, Warszawa.

55. WOJCIUK A., 2016: Imperia wiedzy. Edukacja i nauka jako czynniki sity państwa na arenie międzynarodowe, Warszawa. 